DOI https://doi.org/10.30525/978-9934-588-81-5-2.12

\title{
CHARACTERISTICS OF DELIVERIES NUMBER AND ANALYSIS OF DELIVERY AND POSTPARTUM PERIOD COMPLICATIONS IN WOMEN OF KHARKIV REGION
}

\author{
Myroshnychenko M. S. \\ Doctor of Medical Sciences, \\ Professor at the Department of Pathological Anatomy \\ Kharkiv National Medical University
}

Kapustnyk N. V.

Candidate of Medical Sciences,

Associate Professor at the Department of Obstetrics and Gynecology № 1

Kharkiv National Medical University,

Head of the Gynecological Department № 2

Public Nonprofit Organization of the Kharkiv District Council

«Regional Clinical Perinatal Centre»

Saldan G. M.

Deputy Director for Operations, Disaster Medicine and Civil Protection

Public Nonprofit Organization of the Kharkiv District Council

"Center of Emergency Medical Care and Disaster Medicine»

Selivanova L. I.

Gastroenterologist

Public Nonprofit Organization of the Kharkiv District Council

«Regional Clinical Hospital»

Kharkiv, Ukraine

\section{Myroshnychenko S. O.}

Obstetrician-gynecologist

Public Nonprofit Organization of the Izium City Council "Central City Hospital of Sandy Mother of God»

Izium, Kharkiv region, Ukraine

Saving children health and life is a strategically important and priority task of the state in the field of health care. Children's health affects the future socio-demographic and socio-cultural indicators of the country population [1, p. 2; 3, p. 106].

A healthy start of the child life is determined by the health state of the parents, peculiarities of pregnancy and delivery duration [3, p. 105]. Epidemiological research is extremely important for the improvement of medical care for children, planning the strategic directions of development of 
the health care system of the country and a separate region, rational distribution of material resources, medical staff training [2, p. 103].

The aim is to analyze the quantitative characteristics of deliveries, complications of delivery and postpartum period in women of Kharkiv region.

Material and methods. The material of the study was the reporting documentation of the Communal Health Protection Institution «Kharkiv Regional Informational and Analytical Center for Medical Statistics» for the period from 2016 to 2018. Statistical processing of indicators was performed using Statistica 6.0, Microsoft Excel 2003.

Results. In Kharkiv region, there was a decrease $(\mathrm{p}<0.05)$ of the absolute number of deliveries for the period from 2016 to 2018. Thus, the indicator of the absolute number of deliveries in 2016 was 22929, in 2017 21085 , in $2018-18910$.

Iron deficiency anemia (in 2016 - 2655, 11.58\%; in 2017 - 2449, $11.61 \%$; in $2018-2239,11.84 \%$ ), obstructed labour (in $2016-2218,9.67 \%$; in $2017-1981,9.40 \%$; in $2018-1891,10.0 \%$ ), edema, proteinuria, hypertensive disorders, including preeclampsia and eclampsia (in $2016-1102$, $4.81 \%$; in $2017-1183,5.61 \%$; in $2018-984,5.20 \%$ ), circulatory system diseases (in $2016-895,3.90 \%$; in $2017-904,4.29 \%$; in $2018-783$, $4.14 \%$ ), labor activity anomalies (in $2016-736,3.21 \%$; in $2017-652$, $3.09 \%$; in $2018-569,3.15 \%$ ), thyroid gland diseases (in $2016-721,3.14 \%$; in $2017-679,3.22 \%$; in $2018-677,3.58 \%$ ), venous complications (in $2016-624,2.72 \%$; in $2017-379,1.80 \%$; in $2018-601,3.18 \%$ ), genitourinary system infections (in $2016-606,2.64 \%$; in $2017-548,2.60 \%$; in $2018-564,2.98 \%$ ), bleeding (in $2016-489,2.13 \%$; in $2017-393,1.86 \%$; in $2018-348,1.84 \%$ ), diabetes mellitus (in $2016-135,0.59 \%$; in $2017-$ $137,0.65 \%$; in $2018-148,0.78 \%$ ) were identified among delivery and postpartum period complications in women of Kharkiv region.

Conclusions. In women of Kharkiv region there was a decrease of the absolute number of deliveries for the period from 2016 to 2018. Frequent complications of delivery and postpartum period were iron deficiency anemia, obstructed labour, edema, proteinuria, hypertensive disorders, including preeclampsia and eclampsia. The obtained results indicate the need to increase the work of hospitals in order to conduct effective preconception training for parents, medical activity and family well-being.

\section{References:}

1. Antipkin Yu. G., Volosovets O. P., Maidannik V. G., Berezenko V. S., Moiseenko R. O., Vygovska O. V. et al. Status of child population health - the future of the country. Zdorov'e Rebenka. 2018. No. 13(1). P. 1-11. 
2. Krukovich E. V., Zhdanova L. A., Luchaninova V. N. Risk periods in the formation of the children and adolescents health. Pediatrics. 2007. No. 86 (2). P. 103-106.

3. Ostrovskyi I. M., Prokhorov E. V., Narizhnyi M. Yu. Health of children from the results of the parents' questionnaire. Russian Bulletin of Perinatology and Pediatrics. 2017. No. 62 (3). P. 105-111.

DOI https://doi.org/10.30525/978-9934-588-81-5-2.13

\title{
ДОСЯГНЕННЯ ПОЗИТИВНОГО СОЦІАЛЬНОГО РЕЗУЛЬТАТУ ДЛЯ НАСЕЛЕННЯ ВІД ВПРОВАДЖЕННЯ ГОСПІТАЛЬНИХ ОКРУГІВ
}

\author{
Стовбан М. П. \\ кандидат медичних наук, \\ дочент кафедри фтизіатрії і пульмонологіі \\ з курсом професійних хвороб, \\ заступник генерального директора
}

Комунальне некомериійне підприємство «Івано-Франківська обласна клінічна інфекційна лікарня Івано-Франківської Обласної Ради»

\section{Стовбан I. B.}

кандидат медичних наук, дочент кафедри сочіальної медичини та громадського здоров'я Івано-Франківський національний медичний університет м. Івано-Франківськ, Украӥна

\section{Толстанов О. К.}

доктор медичних наук, професор, професор кафедри управління охороною здоров'я Національна медична академія післядипломної освіти імені. П. Л. Шупика м. Київ, Україна

\section{Гбур 3. В.}

доктор наук з державного управління, професор кафедри управління охорони здоров'я Національна медична академія післядипломної освіти імені. П. Л. Шупика м. Київ, Україна 